\title{
Tunnel Stability Analysis Based on Temporary Support Modeling in The Construction of Hasang Hepp in Toba Samosir District North Sumatra Province
}

\author{
Tengku Tibri $^{1 *}$, M. Eka Onwardana ${ }^{1}$, Ediyasa Ardiansyah ${ }^{1}$, Heri Adhahari ${ }^{1}$ Lismawaty $^{2}$, \\ Bintang Wijaya ${ }^{3}$ \\ \{tengku.tibri@gmail.com*\} \\ ${ }^{1}$ Mining Department- Institut Teknologi Medan. Jl. Gedung Arca No. 52. Medan. Indonesia \\ ${ }^{2}$ Geology Department - Institut Teknologi Medan. Jl. Gedung Arca No. 52. Medan. Indonesia \\ ${ }^{3}$ Fresh Graduate in Mining Department - Institut Teknologi Medan. Jl. Gedung Arca No. 52. \\ Medan. Indonesia
}

\begin{abstract}
Excavation at the tunnel of Hydroelectric Power Plant along 2,650 m has been conducted in Nassau Sub-district Toba Samosir District North Sumatra Province. To determine an appropriate supporting to the tunnel, simulation of supporting system variation using Phase 2 and Unwed must be taken. Displacement analysis is conducted at four point, likes at the point at the roof of the tunnel, point $b$ between roof and the tunnel wall, point $\mathrm{c}$ on the tunnel wall, and point $\mathrm{d}$ on the corner side of the tunnel floor. There are 16 variation of supporting system that implemented to the model. Conclusion from the simulation shows the appropriate supporting system is recommended 1 rockbolt along $6 \mathrm{~m}$, random space, and shotcrete with thickness $50 \mathrm{~mm}$ on floor and the wall.
\end{abstract}

Keywords: Appropriate Supporting Tunnel, Rock Mass Rating, Q-System, Modeling, Phase2, Unwedge.

\section{Introduction}

The Tunnel excavation of Hasang Hydro-electric Power Plant along 2,650 meters under construction in Nassau Sub-district, Toba Samosir District, North Sumatra Province. The tunnel is expected to penetrate Toba tuff with inserting debris flow mud silky stone approaching the end of the tunnel. The tunnel is also closely with the Renun fault of SFS system (Sieh. K and Natawidjaja, 2000).

In the contruction of hydropower tunnels often encountered an unusual problems occurred in the design of ordinary buildings. The problems are heterogeneous rock mass properties, anisotropic, discontinuous and geological factors that are directly related to the forces acting on the initial shear. This is what causes the collapse often occurs in several tunnels are being constructed.

The problems that often occurs in the tunnel construction are unappropriate support system that resulting a failure on the tunnel or apply a bigger safety factor that resulted an excessive of supporting.

The aim of this study is to achieve an appropriate supporting system as a recomendation to support a safety and effective supporting system. The case study conduct on the Hasang Hydroelectric Power Plant which is distance from Medan \pm 282 $\mathrm{km}$ to the southwestward in Nassau Sub-district, Toba Samosir District, North Sumatra 
Province (Figure 1). Hasang HEPP has been proposed as a run-of-river hydropower and it generates $39 \mathrm{MWe}$.

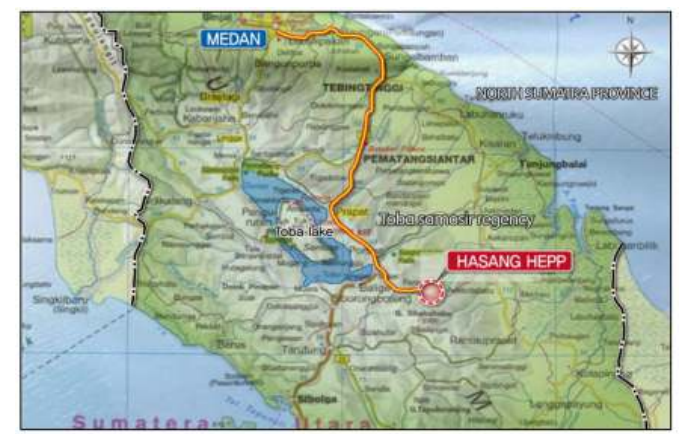

Fig. 1. Location of Hasang HEPP in Toba Samosir District, North Sumatra Province.

\section{Geological Setting}

\subsection{Morphology}

The morphology of study area involves rolling hills with some steeper, incised valleys cut by erosion of streams. Valleys of tributary are generally V-shaped with relatively steep slopes and slope angles between $30^{\circ}$ to $80^{\circ}$. In northwestern part of the site, the stiff mountains above $2,500 \mathrm{~m}$ in elevation are developed in the direction of northwest to southeast and east to west. In northeastern part of the site almost consists widespread lowland plain. The lowest part in the study area is the west side that closely to the Toba Lake with a height of 920 msal. The current is deep and fast though the catchment area is narrow because of steep topography. Streams basin of this site show typical dendritic drainage.

\subsection{Geology Of Study Area}

According to Pematang Siantar geological map, number 0718 (Cameron N.R., 1982), study area are situated on the eastern flank of Barisan Mountains which constitute a back bone of mountain range in the Sumatra.

Stratigraphic sequences show the oldest to youngest rocks in the study area are Mesozoic and/or Paleozoic of sedimentary rocks with poorly bedded conglomeratic wakes and quartzose arenites from Tapanuli group, above the formation is deposited basal conglomerates, sandstones, sometimes glauconitic, siltstones from Peutu formation with age Middle Miocene to Pliocene, followed by Pleistocene volcanic rocks of pumiceouse rhyodacitic tuff with partially welded and columnar jointed from Toba tuff formation, and the youngest formation is Alluvium Holocene consists clays, silts and gravel of river deposits. The bedrocks mainly consists sandstone, shale and phyllites exposed several kilometers west part from study area.

Geology local in the study area mostly consist Quaternary sedimentary and volcanic rocks. Quaternary sedimentary rocks can be divided as tuffaceous sandstone (fine to very fine grained), siltstone, mudstone and shale. The volcanic rocks almost show deictic tuff interbred ignimbrite tuff in upper part. Ignimbrite contains quartz and plagioclase phenocryst and it is seen distributed along Kualu River showing chain to 
band-shaped. In this study area, these Quaternary volcanic rocks called Toba Tuff (Anonim, 2016).

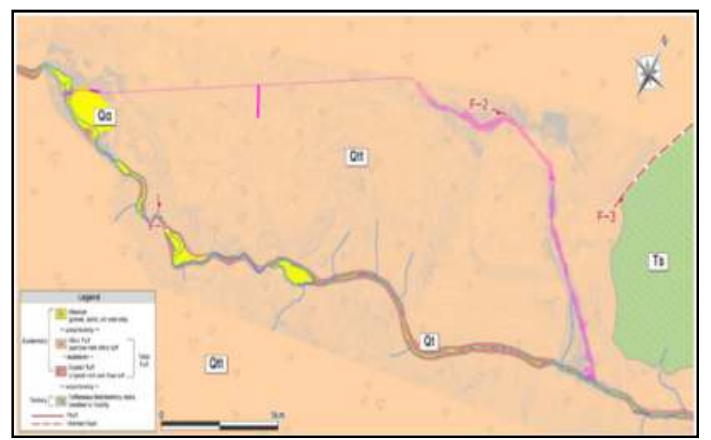

Fig. 2. Detailed Geology in Study Area.

\section{Methodology}

The research methodology to be carried out in this case is a simulation to determine approriate supporting through the small or simple scale system sampling, in which the model will be manipulated or controlled to understand the effect.

The simulation will use the software Phase2 and Unwedge that distributed the strength based finite element concept. Phase 2 will be used for analysis factor stability tunnel from dispalcement, and Unwedge will be used for analysis factor stability tunnel from the problems of structure geology in the tunnel. Output for the Unwedge is value of stability factors (FS). The support that will become model based from rock mass clasification RMR and Q-System, and the physical and mechanical properties of rockmass obtained from the laboratory test.

The supporting to be modeled is based on rock mass quality that assessed through the rock mass classification of RMR and Q-System (Bieniawski Z.T, 1973). Data required for this study include lithology and structure data in tunnel, field test and laboratory data, and tunnel design. The results obtained are input data on Phase2 and Unwedge software. Modeling is done by several stages, likes before the tunnel is supported, the tunnel with the support has been applied in the site, and the tunnel with the support follows to the rock mass classification of RMR and Q-System. Furthermore, supporting recommended by the RMR and Q-System will be simulated for effective and efficient temporary supporting (Cecil, O.S., 1970).

\section{Result And Discussion}

While the study is being conducted, the length of the excavated tunnel already reach 2,560 m with 1 workadit along $160.96 \mathrm{~m}$. Data that we use for this study is length $29 \mathrm{~m}$ at the distance $89-118 \mathrm{~m}$.

\subsection{ROCKMASS CLASSIFICATION In STUDY AREA}

According to the clasification of rock mass RMR, there are two classes of rock in the tunnel namely good rock classes and fair rock classes (Barton, 2013). The good rock found at the position of $89-108 \mathrm{~m}$ and $116-118 \mathrm{~m}$, and fair rock found at the 
position of 108-116 m. The different of classes is caused the descending of RQD value (Tibri, 2008).

The difference of the classes of rock mass according to Q-system is caused by the difference of the number of joints structure in the tunnel. The joint is acted as RQD divided, and more number of joints mean more decrease the assessment of rock mass classification.

\subsection{Tunnel Before Supporting}

The position of the tunnel that analyzed using Phase 2 software is conducted at 4 points, likes point at the tunnel roof, point $b$ between the roof and the tunnel wall. point $\mathrm{c}$ at the tunnel wall, and point $\mathrm{d}$ at the corner side of the tunnel floor. The result analysis using Phase 2 shows the mayor stress $\left(\sigma_{1}\right)$ at the point $a$ is $2.40 \mathrm{Mpa}$, at the point $b$ is $0.15 \mathrm{Mpa}$, point $c$ is $0.0 \mathrm{Mpa}$, and at the point $\mathrm{d}$ is $2.55 \mathrm{MPa}$. The minor Stess $\left(\sigma_{3}\right)$ at the point $a$ is $0.18 \mathrm{Mpa}$, point $b$ is $-0.09 \mathrm{Mpa}$, point $c$ of $-0.22 \mathrm{Mpa}$, and point $d$ of 0.63 $\mathrm{MPa}$. Due to no supporting to the tunnel generates the displacement. Measurement that conducted to the location show the displacement in a day at point $a$ is $0.1 \mathrm{~mm}$, at the point $b$ is $0.45 \mathrm{~mm}$, at the point $c$ is $0.52 \mathrm{~mm}$, and the last at the point $d$ is $0.15 \mathrm{~mm}$. The model shows the displacement can be seen at the Figure 3.

According (Zhenxiang., 1984), at the point $a$ and point $d$ show $a$ stable condition, and at the point $b$ and point $c$ show a relatively unstable condition. According to Unwedge, the value of stability factor for tunnel before installed supporting is 0.616. According (Hoek and Brown, 1980) and (Hoek, 2000) the value for stability factor is $\geq$ 1.5 , the condition above are not stable and most likely to collapse if not supporting immediately.

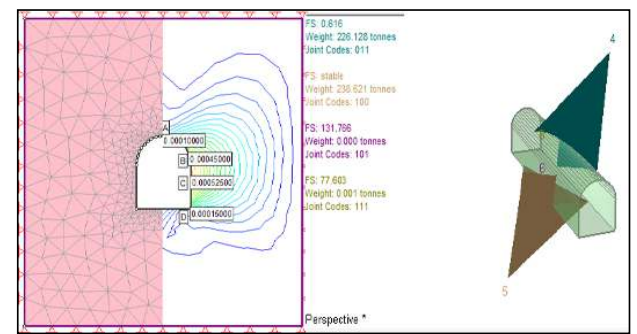

Fig. 3. Total Displacement and Value of Factor Stability Tunnel before Installed

\subsection{Tunnel After Supporting} Support.

Supporting system has been applied on the site are rockbolt and shotcrete. Rockbolt along $2 \mathrm{~m}$ with spacing $2 \mathrm{~m}$, and shotcrete with thick recommendation of 80 mm already implemented on the roof and side of tunnel point $a$ is $2.25 \mathrm{Mpa}$, at the point $b$ is $0.15 \mathrm{Mpa}, a$. Analysis use Phase 2 that conducted to the area of tunnel shows the mayor Stress $\left(\sigma_{1}\right)$ at the $\mathrm{t}$ the point $\mathrm{c}$ is $0.0 \mathrm{Mpa}$, and at the point $d$ is $2.40 \mathrm{MPa}$. The data showed the distribution of mayor stress tend to decrease. The decreasing interpreted as the supporting activities have pressure reaction and it makes the strain distribution being decreased. 


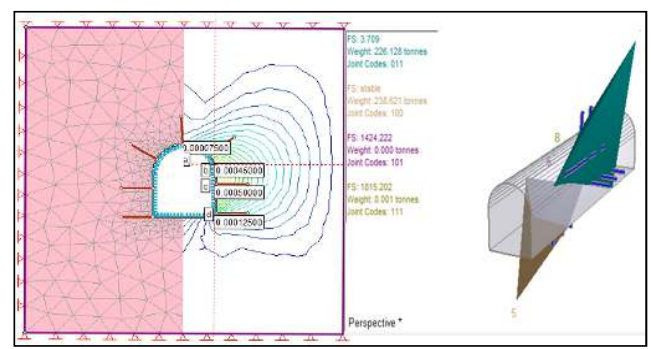

Fig. 4. Total Displacement and Value of Stability Factor for Tunnel after Supporting has been Installed on site.

While the analysis result to the minor stress $\left(\sigma_{3}\right)$ at the point $a$ is $0.28 \mathrm{Mpa}$, at the point $b$ is $-0.12 \mathrm{Mpa}$, at the point $\mathrm{c}$ is $-0.12 \mathrm{Mpa}$ and at the point $d$ is $0.72 \mathrm{MPa}$. Displacement before and after implementing of supporting system shows the difference to the point $a, c$, and $d$. At the point $a$ and point $d$ show the decreasing value of 0.03 $\mathrm{mm} /$ day, and at the point $\mathrm{c}$ the decreasing is $0.02 \mathrm{~mm} /$ day. The displacement at the point $a$ and the point $d$ showing the stable condition while at the point $\mathrm{b}$ and point $\mathrm{c}$ showing relatively stable (Zhenxiang., 1984). Figure 4 shows the displacement and value of stability factor after supporting installed. The value of stability factor after installing the supporting shows the number of 3.709. It means the value is very stable and tends to ineffective.

\subsection{TUNNEL With VARIATION SUPPORTING SYSTEM}

To understand the supporting system and attempt to meet an approriate supporting, we try to simulate the data. Modeling for supporting system that implemented in this study based to rock mass classification RMR and Q-System. There are 16 variation of supporting system that implemented to simulate to the model with Phase 2 and Unwedge softwares. The first variation is implemented while the tunnel is opened and not supporting yet, second variation while the tunnel already supporting, and the third until $16^{\text {th }}$ are implemented with supporting variation categories fair rock according RMR system. Meanwhile, from third until $16^{\text {th }}$ supporting can be selected the approriate support and used as comparation to the other supporting recommended. The result of modeling can be seen at the Table 1 .

The result of modeling shows the variation of $15^{\text {th }}$ is recommended with good rock based on RMR system and variation of $16^{\text {th }}$ is recommended based on Q-System.

Analysis to the mayor stress $\left(\sigma_{1}\right)$ shows the dominant points are relatively decrease. The decrease cause supporting has pressure reaction properties so that reaction press the stess. Analysis minor stress $\left(\sigma_{3}\right)$ overall variation after installing support tend decrease due to the effect of increasing number of support, and vertical stress decrease.

Analysis displacement using Phase 2 to the each of point show the displacements relatively decrease due to implementing of supporting system. Several point show decrease of displacement likes at the point $a, c$, and $d$. Meanwhile, at the point $b$ the displacement visible similarly. While the value of stability factor tunnel overall variation after installing support is tend increase it mean tunnel in stable condition. The stress, displacement, and factor stability to the model can be seen at Figure 5. 
Table 1. Stress. Displacement and Stability Factor on Simulation of Variation

\begin{tabular}{|c|c|c|c|c|c|}
\hline $\begin{array}{c}\text { Supporting } \\
\text { Recommendation }\end{array}$ & $\begin{array}{c}\text { Ana } \\
\text { lysis } \\
\text { poin } \\
t\end{array}$ & $\sigma 1$ & $\sigma 3$ & Displament & FK \\
\hline \multirow[t]{4}{*}{ The tunnel before of Supporting } & $\mathrm{a}$ & 2.40 & 0.18 & 0.1 & \multirow[t]{4}{*}{0.6} \\
\hline & $\mathrm{b}$ & 0.15 & -0.09 & 0.45 & \\
\hline & $\mathrm{c}$ & 0.0 & -0.22 & 0.52 & \\
\hline & $\mathrm{d}$ & 2.55 & 0.63 & 0.15 & \\
\hline \multirow[t]{4}{*}{ The Tunnel After Supporting } & $\mathrm{a}$ & 2.25 & 0.28 & 0.07 & \multirow[t]{4}{*}{3.7} \\
\hline & $\mathrm{b}$ & 0.15 & -0.12 & 0.45 & \\
\hline & $\mathrm{c}$ & 0.0 & -0.12 & 0.5 & \\
\hline & $\mathrm{d}$ & 2.40 & 0.72 & 0.12 & \\
\hline \multirow[t]{4}{*}{ Recommendation for fair rocks } & $\mathrm{a}$ & 2.25 & 0.21 & 0.1 & \multirow[t]{4}{*}{2.7} \\
\hline & $\mathrm{b}$ & 0.15 & -0.14 & 0.45 & \\
\hline & $\mathrm{c}$ & 0.00 & -0.14 & 0.5 & \\
\hline & $\mathrm{d}$ & 2.40 & 0.71 & 0.15 & \\
\hline \multirow{4}{*}{$\begin{array}{l}\text { Recommendation for good } \\
\text { rocks }\end{array}$} & $\mathrm{a}$ & 2.25 & 0.21 & 0.1 & \multirow[t]{4}{*}{2.6} \\
\hline & $\mathrm{b}$ & 0.15 & -0.14 & 0.45 & \\
\hline & $\mathrm{c}$ & 0.00 & -0.14 & 0.5 & \\
\hline & $\mathrm{d}$ & 2.40 & 0.71 & 0.15 & \\
\hline \multirow{4}{*}{$\begin{array}{l}\text { Recommendation for Suporting } \\
\text { system }\end{array}$} & $\mathrm{a}$ & 2.25 & 0.21 & 0.1 & \multirow[t]{4}{*}{2.1} \\
\hline & $\mathrm{b}$ & 0.15 & -0.14 & 0.45 & \\
\hline & $\mathrm{c}$ & 0.0 & -0.14 & 0.5 & \\
\hline & $\mathrm{d}$ & 2.40 & 0.71 & 0.15 & \\
\hline
\end{tabular}

\subsection{DETERMINATION For EFFECTIVE SUPPORTING SYSTEM}

From simualation variation modeling supporting system, which is the most effective support is recomendation from Q-system. The recommended supporting system are using rock bolt along $6 \mathrm{~m}$, random spacing. The quantity of supporting system that recommended is smaller than other. This recommended supporting system will reduce $8 \mathrm{~m}$ of each used rock bolt and also this support will reduce using shotcrete untill $20 \mathrm{~mm}$ thick.

(a)

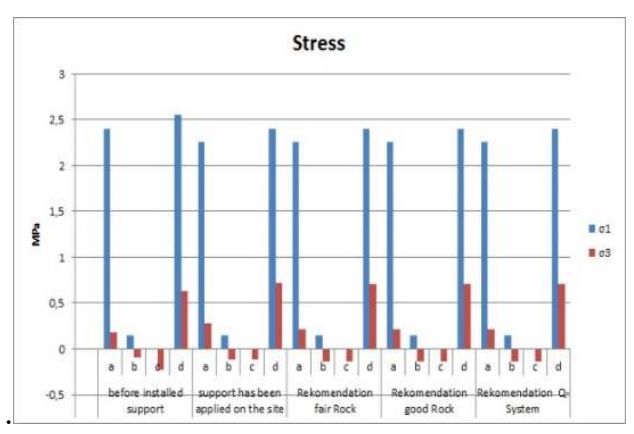


(b)

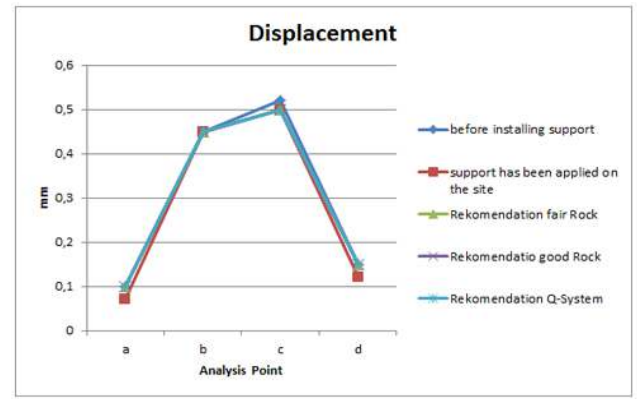

(c)

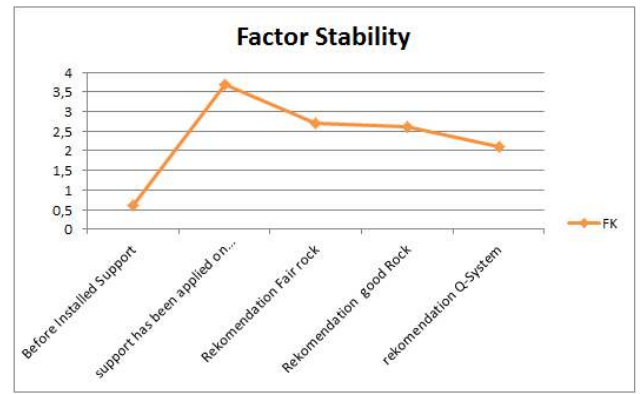

Fig. 5. The graphic for (a) Stress, (b) Displacement, and (c) Stability Factor that resulted from modeling.

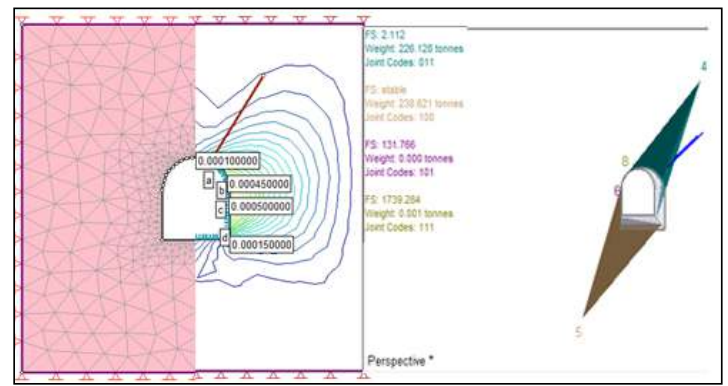

Fig. 6. Recomendation for the best Effective Supporting with Variation model

\section{Conclusions}

1. According RMR system, there are two classes of rocks at the tunnel analyzed, fair rock and good rock. According to the class of rock mass Q-System, there are four classes of rockmass on the tunnel, likes extremely rock, very good rock, good rock, fair rock. These differences to the tunnel due to the number of joint present on the tunnel.

2. Tunnel before installed of supporting from total displacement on the roof is showing stable condition and on the side showing relatively condition. While factor stability is unstable. 
3. Tunnel with supporting system has been applied on the site. Dispalcement on the roof showing stable condition and on the side showing relatively stable condition. While the value of stability factor showing very stable condition.

4. From simulation variation supporting system an effective recomendation support for tunnel is recomendation Q-system. Recomeendation support is 1 rockbolt along $6 \mathrm{~m}$ and random spacing. While shotcrete $50 \mathrm{~mm}$ on the roof and side, this support is the most effective than other variation support. This recommedation will reduce using rockbolt untill $8 \mathrm{~m}$ lenght every $1 \mathrm{~m}$ on the tunnel length. While also this support reduce using shotcrete until $20 \mathrm{~mm}$ of thickness.

\section{Acknowledgements}

Initial work leading to this article was carried out in collaboration with my colleagues Mr. Alfian as a geologist tunnel analysis of PT. Binsar Natorang Energy. We also thank to the management of company that give us chance to expose the data.

\section{References}

[1] Anonim (2016) 'Geotechnical Inverstigation Report Hasang Hydroelectric Power Plant in Indonesia'.

[2] Bieniawski Z.T (1973) 'Rock Mechanics Design In Mining And Tunneling, The Pennsylvania State University. Boston'.

[3] Cameron N.R., et. all (1982) 'Geologic Map of the Pematang Siantar Quadrangle, Sumatra. Geological Research and Development Centre, Wast Java.'

[4] Cecil, O.S. (1970) 'Correlation of Rockbolt-Shotcrete Support and Rock Quality Paramaters in Scandinavian Tunnels, Ph.D thesis, University of Illionis, Urbania.'

[5] Hoek (2000) 'Predicting Tunnel Squeezing in Weak Heterogeneus Rock Massed, Tunel and Tunneling Internasional, part 1.'

[6] Hoek and Brown (1980) 'Underground Excavation in Rock, The Institution of Mining And Metallurgy.'

[7] Sieh. K and Natawidjaja (2000) 'Neotectonics of Sumatran Fautl, Indonesia, Journal of Geophysical Research', Journal of Geophysical Research, 105, p. 28.295-28.326.

[8] Tibri, T. (2008) 'Analisis Kestabilan Terowongan Jalan Menggunakan Metode Empirik dan Analitik di Desa Sibaganding Kabupaten Simalungun Provinsi Sumatera Utara, Seminar Nasional. Peningkatan Sumberdaya Manusia dan Industri Berbasis Universitas Riset, Fakultas Teknik UISU.'

[9] Zhenxiang., X. A. (1984) 'Tunnel Design Methode Using Field Measured Data.', in Procceeding of ISRM Symposium Design And Peformance of Underground Excavation,. London.

\section{Appendices}


MAYOR And MINOR STRESSES ANALYSIS $\left(\Sigma_{1}\right.$ And $\left.\Sigma_{3}\right)$

\begin{tabular}{|c|c|c|c|c|c|c|c|c|c|c|c|c|}
\hline \multirow{2}{*}{$\begin{array}{c}\text { Supporting } \\
\text { Recommendation }\end{array}$} & \multirow[t]{2}{*}{ Stages } & \multirow[t]{2}{*}{ Shotcretes } & \multicolumn{2}{|c|}{ Rockbolts } & \multicolumn{4}{|c|}{$\sigma_{1}(\mathrm{MPa})$} & \multicolumn{4}{|c|}{$\sigma_{3}(\mathrm{MPa})$} \\
\hline & & & $\begin{array}{c}\text { Spacing } \\
(\mathrm{m})\end{array}$ & $\begin{array}{l}\text { Length } \\
\text { (m) }\end{array}$ & $\mathbf{a}$ & $\mathbf{b}$ & c & D & $\mathbf{a}$ & b & c & d \\
\hline Before Suporting & 1 & - & - & - & 2.40 & 0.15 & 0.0 & 2.55 & 0.18 & -0.09 & -0.22 & 0.63 \\
\hline After Suporting & 2 & 80 & 2 & 2 & 2.25 & 0.15 & 0.0 & 2.40 & 0.28 & -0.12 & -0.12 & 0.72 \\
\hline \multirow{12}{*}{ 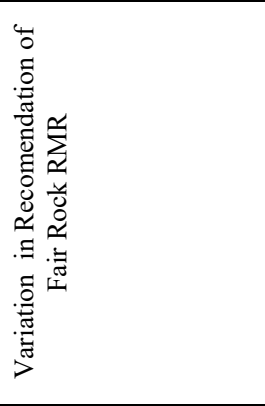 } & 3 & 50 & 1.5 & 4 & 2.25 & 0.15 & 0.0 & 2.40 & 0.21 & -0.09 & -0.14 & 0.71 \\
\hline & 4 & 50 & 2 & 4 & 2.25 & 0.15 & 0.0 & 2.40 & 0.21 & -0.14 & -0.14 & 0.66 \\
\hline & 5 & 50 & 1.5 & 3 & 2.25 & 0.15 & 0.0 & 2.40 & 0.21 & -0.09 & -0.14 & 0.71 \\
\hline & 6 & 50 & 2 & 3 & 2.25 & 0.15 & 0.0 & 2.40 & 0.21 & -0.14 & -0.14 & 0.71 \\
\hline & 7 & 100 & 1.5 & 4 & 2.1 & 0.15 & 0.0 & 2.25 & 0.27 & -0.13 & -0.13 & 0.77 \\
\hline & 8 & 100 & 2 & 4 & 2.1 & 0.15 & 0.0 & 2.25 & 0.27 & -0.13 & -0.13 & 0.77 \\
\hline & 9 & 100 & 1.5 & 3 & 2.1 & 0.15 & 0.0 & 2.25 & 0.27 & -0.13 & -0.13 & 0.77 \\
\hline & 10 & 100 & 2 & 3 & 2.1 & 0.15 & 0.0 & 2.25 & 0.27 & -0.13 & -0.13 & 0.77 \\
\hline & 11 & 150 & 1.5 & 4 & 2.1 & 0.1 & 0.1 & 0.22 & 0.32 & -0.14 & -0.09 & 0.77 \\
\hline & 12 & 150 & 2 & 4 & 2.1 & 0.1 & 0.1 & 0.22 & 0.32 & -0.14 & -0.09 & 0.77 \\
\hline & 13 & 150 & 1.5 & 3 & 2.1 & 0.1 & 0.1 & 0.22 & 0.32 & -0.09 & -0.09 & 0.77 \\
\hline & 14 & 150 & 2 & 3 & 2.1 & 0.1 & 0.1 & 0.22 & 0.32 & 0.09 & -0.09 & 0.77 \\
\hline Good Rock (RMR) & 15 & 50 & 2.5 & 3 & 2.25 & 0.15 & 0.0 & 2.40 & 0.21 & -0.14 & -0.14 & 0.71 \\
\hline Q-System & 16 & 50 & - & 6 & 2.25 & 0.15 & 0.0 & 2.40 & 0.21 & -0.14 & -0.14 & 0.71 \\
\hline
\end{tabular}

\section{DISPLACEMENT ANALYSIS And SAFETY FACTOR}

\begin{tabular}{|c|c|c|c|c|c|c|c|c|c|c|}
\hline \multirow{2}{*}{$\begin{array}{c}\text { Supporting } \\
\text { Recommen } \\
\text { dation }\end{array}$} & \multirow[t]{2}{*}{ Stages } & \multirow[t]{2}{*}{ Shotcretes } & \multicolumn{2}{|c|}{ Rockbolts } & \multicolumn{5}{|c|}{ Displacement (mm) } & \multirow{2}{*}{$\begin{array}{c}\text { Safety } \\
\text { Factor } \\
\text { (FK) }\end{array}$} \\
\hline & & & $\begin{array}{c}\text { Spacing } \\
\text { (m) }\end{array}$ & $\begin{array}{c}\text { Length } \\
\text { (m) }\end{array}$ & $\mathbf{a}$ & $\mathbf{b}$ & c & d & Total & \\
\hline $\begin{array}{c}\text { Before } \\
\text { Suporting }\end{array}$ & 1 & - & - & - & 0.1 & 0.45 & 0.52 & 0.15 & 0.1 & 0.616 \\
\hline $\begin{array}{c}\text { After } \\
\text { Suporting }\end{array}$ & 2 & 80 & 2 & 2 & 0.07 & 0.45 & 0.50 & 0.12 & 0.07 & 3.709 \\
\hline \multirow{12}{*}{ 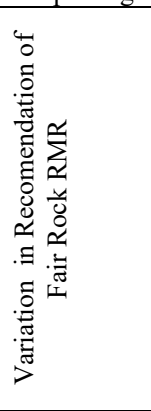 } & 3 & 50 & 1.5 & 4 & 0.07 & 0.45 & 0.50 & 0.15 & 0.07 & 2.834 \\
\hline & 4 & 50 & 2 & 4 & 0.07 & 0.45 & 0.50 & 0.15 & 0.07 & 3.028 \\
\hline & 5 & 50 & 1.5 & 3 & 0.07 & 0.45 & 0.50 & 0.15 & 0.07 & 2.773 \\
\hline & 6 & 50 & 2 & 3 & 0.1 & 0.45 & 0.50 & 0.15 & 0.1 & 3.028 \\
\hline & 7 & 100 & 1.5 & 4 & 0.07 & 0.45 & 0.50 & 0.12 & 0.07 & 4.245 \\
\hline & 8 & 100 & 2 & 4 & 0.07 & 0.45 & 0.50 & 0.15 & 0.07 & 4.435 \\
\hline & 9 & 100 & 1.5 & 3 & 0.07 & 0.45 & 0.50 & 0.12 & 0.07 & 4.1 \\
\hline & 10 & 100 & 2 & 3 & 0.07 & 0.45 & 0.50 & 0.12 & 0.07 & 4.435 \\
\hline & 11 & 150 & 1.5 & 4 & 0.07 & 0.45 & 0.47 & 0.12 & 0.07 & 5.597 \\
\hline & 12 & 150 & 2 & 4 & 0.07 & 0.45 & 0.47 & 0.12 & 0.07 & 5.784 \\
\hline & 13 & 150 & 1.5 & 3 & 0.07 & 0.45 & 0.47 & 0.12 & 0.07 & 5.539 \\
\hline & 14 & 150 & 2 & 3 & 0.07 & 0.45 & 0.47 & 0.12 & 0.07 & 5.784 \\
\hline $\begin{array}{c}\text { Good Rock } \\
\text { (RMR) }\end{array}$ & 15 & 50 & 2.5 & 3 & 0.1 & 0.45 & 0.5 & 0.15 & 0.1 & 2.644 \\
\hline Q-System & 16 & 50 & - & 6 & 0.1 & 0.45 & 0.5 & 0.15 & 0.1 & 2.112 \\
\hline
\end{tabular}

